\title{
政策、社会、空间
}

\section{一一 法国大型居住社区的建设与治理（1850一2010年）}

\author{
Policy, Society, Space: Construction and Governance of French Large-scale Community (1850-2010)
}

摘要: 保障性住房是中国政府和公众关注的重大问 题。本文从政策、社会、空间三个角度入手, 分四个 时期, 即工人城（1850-1890 年代）、花园城（18901930 年代)、大型居住社区（1945-1973 年）、更新 与治理（1973-2010 年), 对法国一个半世纪以来的 大型居住社区的建造过程、问题和对策进行梳理, 并 提出法国经验对中国保障房社区建设的借鉴意义。

Abstract: The indemnificatory apartment is a main concern of the Chinese government and the public. The paper analyses the history, problems and countermeasures of social housing in France in four phases: working-class neighborhood (1850-1890s), garden city (1890s-1930s), large-scale community (1945-1973) and urban renewal and Community governance (1973-2010). Each phase is introduced in three perspectives: policy, society and space. The paper reflects the signification of the France experience as a good reference to China's construction of indemnificatory apartment.

关键词: 大型居住社区; 法国经验; 城市更新; 社区治理

Keywords: Large-scale Community; France Experience, Urban Renewal; Community Governance

上海市浦江人才计划 (14PJ1408900)、同济大学人 文社会科学青年基金（0100219146）共同资助

\section{引言}

住房涉及民生, 是政府和公众关注的重大社会问题。自 1990 年代开始, 国务院和建设部多次提出“建立以中低收人家庭为对象的、具有社会保障性 质的经济适用房供应体系”。2007 年以后, 北京、上海、广州、重庆等大城 市陆续推出了保障房计划。截至 2012 年, 全国开工的保障房已达到 1700 余万套。保障房的大规模建设在改善中低收人居民的住房条件、疏散中心城 区人口和推动新城建设方面发挥了巨大作用, 但在空间、社会和城市治理方 面也引发了诸多讨论。现有的保障房社区 ${ }^{1}$ 研究主要集中在 “空间规划的总 结与反思” ${ }^{[1-3]}$ 和 “住房政策与社区治理” ${ }^{[46]}$ 两方面, 在综合性分析和国际 比较等方面尚显不足。实际上, 自工业革命至二战后的重建, 以法国、德国、 荷兰为代表的欧洲国家在城市郊区曾大规模建造社会住宅。1970 年代以来, 随着中产阶级的迁出和外来移民和低收人者聚居郊区, 这些大型社区普遍出 现了衰败现象, 有些甚至成为引发社会矛盾和城市骚乱的敏感地区, 这引起 了规划师和社会学家学者长达 40 年的研究。本文从政策、社会、空间三个 角度人手, 分四个时期, 即工人城 (Cité Ouvrière, 1850-1890 年代)、花 园城（Cité Jardin, 1890-1930 年代)、大型居住社区 (Grands Ensembles, 1945 -1973 年)、更新与治理（1973-2010 年), 对法国一个半世纪 (18502010 年) 以来大型居住社区的建造过程、问题和对策进行梳理, 最后提出 对中国保障房社区建设的借鉴意义。

\section{1 法国语境下的大型居住社区}

法国语境下的大型居住社区是个多学科建构的概念, 作为专业术语最早 出现于 1935 年的《今日建筑》 (L'Architecture d'Aujourd'hui), 作者为规划师霍 提瓦 (Rotival) ${ }^{[7]}$ 。1950 年代的地理学家迪福 (Dufaux) 等给出定义, 认为 大型居住社区是一种 “大体量的集合住宅”, 通常认为 “这是一种新的、集

作者: 杨辰, 博士, 同济大学建筑与城市规划学院讲师。yangchen@tongji.edu.cn

(1) 21 世纪以来, 中国大城市的保障房社区需求大、建设集中、规模也较大。以上海为例, 2009 年规划建造的 23 片保障房基地总面积 $105 \mathrm{~km}^{2}$ (平 均规模达到 $5 \mathrm{~km}^{2}$ ), 容纳人口 187 万。正是由于超大规模, 不少学者将这一时期的保障房社区称为“大型居住社区”。中国大型居住社区与法 国大型居住社区虽有不少共同点, 但其含义以及产生大型居住社区的政治、经济和社会背景仍有明显的差异。 
约化的建造方式, 有助于郊区现代化, 阻止低密度房地产开 发造成的城市蔓延……常包含五百至上千户居民, 配有相对 完善的公共服务设施” ${ }^{[81}$ 。1 970 年代随着建设速度放缓, 不 少社会学家意识到, 大型居住社区实际上 “为不同的社会群 体提供了一种高密度混居的生活方式, 虽然这一尝试并不总 是成功的” ${ }^{19]}$ 。在 1990 年代的反思中, 历史学家进一步拓 展了对大型居住社区的理解, 认为 “二战后特殊的社会经济 背景、城市住宅的快速建造, 以及 1980 年代以来对敏感街 区的治理” 也是定义大型居住社区的重要维度 ${ }^{[10]}$ 。时至今 日, 我们在学术文献和法律文本中尚未找到一个标准定义, 但学者普遍认为法国大型居住社区具有以下四方面的特点 :

(1) 发源于 19 世纪中叶的工人城, 成形于两次世界大战之 间（1919-1938 年）的花园城, 在战后光辉 30 年（19451975 年) 达到顶峰, 1980 年代以后逐渐式微并成为敏感街 区; (2) 大型居住社区通常选址在城市边缘地区, 是根据现 代主义原则大规模建造的、带有福利性质的集合住宅; (3) 大型居住社区是低收人群体和外来移民的聚居地, 居民的社 会构成具有显著特征; (4) 在投资、建造、更新、治理等政 策制定和实施过程中, 大型居住社区逐渐形成了一套完整的 居住制度。简言之, 法国大型居住社区是一段历史, 一种住 宅类型, 一种生活方式, 也是一种居住制度。

\section{2 社会主义乌托邦一一工人城}

19 世纪的工业革命给法国城市带来了技术和财富, 也 带来了人口激增、住房拥挤和公共卫生等问题, 特别是工人 恶劣的居住状况引起了执政者和知识分子的关注。然而, 要 在城市空间中清晰地划分出工人街区并不容易——除了工厂 周边的棚户区, 法国城市内部的居住混合度相当高 : 低收人 住宅紧贴着豪华公寓, 即便在一栋公寓内部, 不同阶层占据 不同楼层也是常见的现象。可以说, 19 世纪上半叶的工人 群体在职业、生活方式、集体行动等方面或许正在形成一个 阶级 ${ }^{[11]}$, 然而在这一过程中, 居住空间尚未成为他们身份建 构的一个维度。

19 世纪中叶, 法国出现了专门为工人家庭设计的住 宅一工人城。工人城的建设受三股力量的推动 : 首先是国
家意志。在拿破仑三世的支持下，1850 年法国通过了第一 部《公共卫生法》(Loi Salubrité), 旨在改善棚户区卫生和 居住条件, 避免重蹈 1848 年革命的覆辙 ${ }^{1}$; 其次是工人组 织。工业革命伴随着工团主义 (syndicalisme) 兴起, 为满足 工人需求并响应帝国政策, 工人合作社采用集资建房的方式 来解决住房拥挤和高房租压力 ${ }^{2}$; 最后是有慈善精神的企业 家。这些企业家大多受傅里叶思想的影响, 希望为底层劳工 建立一个同工同住的和谐社区, 提供过去只有资产阶级才能 享受的居住环境, 改善工人莬迫的生活状况和被机器生产异 化的精神世界, 从而实现财富平均和社会改良的目的 ${ }^{3}$ 。乌 托邦式的社会主义很有吸引力, 但实施起来并不容易, 直到 1870 年代, 享受企业建房的工人家庭仅占工人总数的 $1 \%$ 多 一点 ${ }^{[12]}$ 。

根据区位和规模的不同, 工人城大致呈现三种形态。一 种是市区的 “工人公寓”。这类住宅一般由国家投资，占据 半个或一个街坊, 采用围合式布局。虽然楼内提供卫生、幼托、 医疗等基本服务, 但居民的日常生活主要依靠城市街道的公 共设施。第二种是城市边缘的 “工人新村”。这类住宅由工 人合作社和地方政府联合开发, 目的是促进工业生产。新村 一般紧邻工厂, 占地大, 建筑密度低, 配有少量的公共服务 设施。第三种是城市远郊的 “工人之家”。这类住宅大多由 企业主个人出资, 规模适中。由于远离市区, 工人之家配有 完善的公共服务设施, 有些还包含生产车间和菜园一一方便 通勤、解决工人家庭后顾之忧的同时, 也利于培养一种集体 主义的生活方式。

工人城被视为大型居住社区的维形是因为, 与同时代的 私人住宅相比, 工人城的开发规模较大, 属于非营利性（绝 大部分为廉租房), 且无论是公寓、新村还是工人之家, 都 努力营造一种社区氛围。法语中的 “城” (cité) 意味着 “有 明确的空间边界, 成员相对同质, 且进行自我管理的共同体”。 这说明除了解决住房和公共卫生等实际问题, 工人城还带有 社会改良的目的一一通过划定居住区域对工人群体进行物质 和精神世界的改造。然而, 19 世纪后半叶帝国的主要任务 是首都改造 (奥斯曼计划), 加上政局动荡, 工人城的建设 量十分有限, 其示范意义远大于实际效果。

(1) 1851 年政府出资的全法第一个工人城在巴黎建成。这座以 “拿破仑三世”命名的工人城是一栋四层回廊式集合住宅, 性质为租货房。整栋建 筑包含 86 套住宅, “采暖、上下水设施和低廉的租金” 对于当时住棚户区的工人阶级来说已是极大的改善。虽然受到保守主义者和周边居民的 反对 (当时的工人被视为暴乱的积极参与者), 这座工人公寓还是在巴黎九区顺利落成。

(2) 米卢斯市 (Mulhouse) 建于 1853-1897 年间的工人住宅区是合作建房的代表。它位于四家大型的纺织和印刷厂之间,占地约 $60 \mathrm{hm}^{2}$, 分三期建成, 共容纳 1243 户口人家庭。

(3) 1865 年机器制造商戈丹 (Godin) 在法国北部小镇吉斯（Guise）建造的 “工人之家” (Familistère de Guise) 是19世纪法国工人城的杰出代表。 该项目占地 $6 \mathrm{hm}^{2}$, 由生产区和生活区两部分组成: 前者包括锻造车间、办公区和菜园, 后者包括住宅单元以及幼托、学校、商店、洗衣房、剧院、 公园等公共设施。每组单元内部设有集会大厅, 整个工人之家容纳工人家庭近 500 户。工人之家直到 1968 年才停止使用, 1991 年被列为法国 国家古迹。 


\section{3 为工人阶级服务一一花园城}

1870 年普法战争之后法国进人了第三共和国时期，随 之而来的巴黎公社运动让执政者意识到，只有让无产者成 为有产者, 社会稳定才有真正的可能一一社会住房应当引 人私有产权。1 894 年, 法国通过了《施格弗莱德法案》(la loi Siegfried), 首次提出将廉价房 (HBM) 作为社会住房的 主体, 并赋予中央政府 “减免税收、设立公积金和向慈善机 构贷款”三项权力来介人社会住房的建设。1906 年的《斯 特劳斯法案》(la loi Strauss) 规定, 国家有责任对社会住房 的质量进行监督, 有必要 “加大土地供应” 和 “补贴开发公 司” 来加快廉价房的建设。1912 年的《博纳韦法案》(la loi Bonnevay）继续强化国家的引导：中央政府可在地方设立派 出机构（廉价房办公室），负责社会住房的推动工作。经过 一系列的法律推动, 全法在一战前成立了 20 余家廉价房办 公室、上百家廉价房开发公司和企业合作社。然而, 由于地 方政府和开发商动力不足 (前者担心私有业主的反对, 后者 更愿意开发商品房)，以及投资分担和利益共享机制不明， 这些机构在 1920 年代之前只零星建成了几千套廉价房, 其 中大部分延续了工人城模式。

真正的变化出现在一战后。战争造成了住房短缺, 开 发商趁机在郊区大肆投机房地产, 城市出现了无序蔓延。面 对选民的压力，地方政府意识到了建造社会住宅的紧迫性。 1919 年法国颁布了第一部《城市规划法》(Loi Cornudet), 对住宅开发项目作出三项规定 : (1) 土地出让之前必须编 制详细规划并获得审批，编制和审批的权力在地方政府;

（2）公共服务设施用地必须占到住宅开发总用地的四分之 一; (3) 市政投资由政府和开发商各负担一半。1928 年通过 了著名的《卢舍尔法案》(la loi Loucheur), 明确了国家社会 住房建设的时间表—“ 10 年为工人阶级提供 50 万套廉价 房”。这一雄心勃勃的计划得到地方政府的积极响应, 短短五 年间（1928一1933 年）全国新增廉价房 12.6 万套, 1939 年 达到 30 万套。虽然 1933 年经济危机影响了计划的实施, 但 这一数量已占新建住宅总量的 $15 \%$, 而这一比例在 1920 年 还不足 $3 \%^{[12]}$ 。

两次世界大战之间的社会住宅建设既有国家的介人，也 有社会组织的参与。这些组织中, 除了直接参与建造的混合 公司和合作社, 还出现了一些颇有影响力的民间社团。战前 “工人之家” 的实践让企业家意识到, 改变工人阶级的生活
状况不能仅靠个人的慈善精神, 要动员更广泛的社会力量, 影响政府决策。一批具有共同理想的企业家、政治家、基督 教徒和天主教徒、第一代工团主义者以及知识分子逐渐走到 一起, 从学术研讨到实地调查, 从公共卫生到社会福利, 全 面探讨解决社会问题的途径和方法。这类社团中影响最大 的是成立于 1894 年的 “社会研究院基金会” (Musée social)。 作为一家公益性质的基金会, 社会研究院基金会的成员来自 各行各业, 但都坚持以非革命的方式进行社会改良。他们积 极为童工争取权益, 利用世博会展出工人生活调查和工人城 实践。他们中的工程师对公共卫生、社会住房和城市规划提 出了很多原创性的思考, 社会学家则对财富再分配和国民互 助进行了制度设计一一这些有关 “福利社会” 的讨论逐渐被 民众所接受, 成为第三共和国的立法基础, 其主要参与者在 日后也成为中央各部及地方政府的领导者, 他们的思想在很 大程度上决定了 20 世纪法国公共政策的走向 ${ }^{1}$ 。

这一时期法国廉价房社区也出现了新的形态一一花园 城。这一名称显然受到霍华德 “田园城市” 的影响 ${ }^{2}$, 在田 园城市理论的信仰者、塞纳省议会主席, 同时也是社会研 究院基金会主要成员的亨利 - 塞利耶 (Henry Sellier) 的推 动下, 法国的大城市 (巴黎、里昂、兰斯等) 在一战结束 后陆续在郊区尝试建造花园城。花园城虽然有疏散中心城 区人口的意图, 但它不是 “田园城市” 的简单翻版。首先, 花园城住宅是廉价房, 服务对象主要是中低收人居民, 特 别是工人阶级, 不是全体市民; 其次, 花园城以居住为主, 不要求每个单元都做到职住平衡或自给自足, 而是利用完 整的公共设施, 对居民的日常生活进行家长式管理（这一 点延续了工人城模式）; 其三, 花园城的选址和规模并不遵 循田园城市的理论, 它更多依附于现有工业区, 并根据企 业和所在城市的需求来决定人口和用地规模（更接近托尼 . 加尼埃 [Tony Garnier] 的工业城市理论) ; 最后, 受现代主义 建筑思潮, 特别是柯布西耶的影响, 花园城采用多层高密 度的开发模式一一正是从这时开始, 法国的社会住房逐步 形成了 “大型居住社区” 的空间特征, 也与田园城市和工 人城拉开了距离。

\section{4 在最短时间建造最多的住宅一一大型居住社区}

二战造成了法国 2000 多个市镇被破坏, 60 万套住宅 被毁, 130 万套严重受损, 政府再次面临战后重建的艰巨 任务。为填补每年 30 万套住房的缺口, 国家从五个方面

(1) 例如社会住宅相关法案的重要推手施格弗莱德、斯特劳斯和卢舍尔都是社会研究院基金会的成员，他们后来分别成为“工商业部”、“卫生与社 会保险部”、“劳动和社会福利部”部长，其政治理念也得到推广。

(2) 1902 年霍华德的《田园城市》法译本出版。第二年社会研究院基金会成员乔治 - 伯努瓦一列维（Georges Benoit-Lévy）在巴黎成立了法国田园城 市协会, 并动员企业家模仿田园城市模式（低密度独立别照）在巴黎郊区建设花园城。但由于战争原因, 该计划并未实施。 
全力推动住房建设：(1) 成立 “重建与城市规划部”, 对 1919 年《城市规划法》进行修订 ${ }^{1}$; (2) 实施以社会住房 为导向的财政改革 ${ }^{(2)}$; (3) 重建租赁房市场, 即取消 1914 年制定的最高租金限制, 鼓励私人业主自建出租, 并根据 房屋条件对租金进行分级设定; (4) 扩大社会住房组织, 引人多元投资渠道; (5) 推广标准化构件和混凝土快速建 造技术。

经过短暂的准备, 战后重建进人加速期, “在最短时间 建造最多的住宅” 成为压倒一切的口号。从 1948 年的 6.7 万套到 1957 年的 27.4 万套, 10 年新建住宅 128.2 万套, 年 均增长率 $22.5 \%$, 仅 1957 一年的建设量就相当于《卢舍尔 法案》实施后 10 年建设量的总和 ${ }^{[13]}$ 。城市住房短缺的现 象得到了部分缓解, 但新的问题也随之而来。首先, 地方 政府为了节约造价, 采用 “在廉价的土地上集中建造” 的 原则, 使得新建住房大多远离市区和产业区, 且规模庞大。 其次, 由于建设速度过快, 地方政府和开发商未能对社区 公共服务设施的供给量作出正确预判, 远郊大型居住社区 普遍缺乏教育、医疗、商业、公交以及就业岗位一一在私 人汽车尚未普及的年代, 这无异于把居民置于荒漠。鉴于 此, 1958 年法国出台了 “优先城市化地区” (ZUP) 政策 ${ }^{3}$, 及时将大型居住社区建设纳人法定城市规划体系, 规定:

（1）大型居住社区开发的主体必须是地方政府、公共机构 或政府控股的混合公司；（2）100 套以上的住宅开发必须设
立 ZUP ; (3) 纳人 ZUP 的住宅开发必须配置相应的公共服 务设施 ${ }^{4}$ 。此后 10 年, 全法共设立 197 个 ZUP, 建成住宅 220 万套。然而, 法定规划的身份并没有让大型居住社区彻 底摆脱困境: 超大规模、就业岗位缺乏、通勤时间长、公 共设施配套与居民实际需求之间的差距等问题, 仍然加剧 着大型居住社区的负面评价。城市学者认为, 这些问题很 大程度上是由于对大型居住社区的理解仍然停留在 “居住 区”, 而不是一个完整的市镇单元（虽然其人口规模远超一 般市镇) ${ }^{[14]}$ 。此外, 在大型居住社区规划的前期, 也缺少一 个在国家、地方政府、规划部门和私人业主之间的协商过程， 使得公共服务设施的规划与实施出现了严重脱节 ${ }^{[15]}$ 。针对 这两个问题, 中央政府从 1960 年代末开始, 对大型居住社 区政策作了两个重要调整：一是探索新城建设 ${ }^{5}$, 二是对 大型居住社区规划的法定框架进行更新一一用 “协议开发 区” (ZAC) (6替代 ZUP。法定规划框架 (ZUP 和 ZAC) 有 力地推动了大型居住社区建设, 保障了公共服务设施的基 本水平, 同时也将国家干预进一步合法化 ${ }^{7}$ 。

值得注意的是, 战后的住房短缺是全方位的, 早期的 大型居住社区既有为中低收人家庭提供的廉价房、廉租房, 也有为中产阶级提供的商品房。大型居住社区在人口构成 方面没有显著的特征一这在 1960 年代初的一份调查报 告中得到了印证 ${ }^{8}$ 。然而, 1970 年代以后的一系列社会经 济变革使得大型居住社区的人口构成发生了很大的变化。

(1) 修订内容主要有三项: (1) 建立国家规划委员会, 在省、市镇、区 (arrondissement) 三级政府设置规划总监 (对中央政府负责), 负责重建工作; （2）规定跨行政边界的住宅开发项目由国家牵头, 协调相关市镇的法定规划；(3) 对于公益性城市项目 (如社会住房), 在不改变土地使用状 态的前提下, 土地所有人用地役权的损失将不予赔偿。

(2) 包括：(1) 个人购买房屋贷款利率减低至 $2 \%$, 还款时间放宽至 75 年; (2) 开发商可根据开发面积, 获得相应的国家住房建设补贴; (3) 国 家储蓄银行货款业务首次向廉租房机构和不动产借贷公司开放;（4）员工数超过 10 人的私营企业，抽取工资的 $1 \%$ 作为住房建设基金。

(3) ZUP 是法国在 1959-1967 年间为新建住宅区设立的法定规划, 其任务是划定郊区大型居住社区的开发范围(作为优先城市化地区), 由中央 和地方政府协调开发商和施工单位，在最短时间内完成土地出让、基础设施延伸、住宅以及公共服务设施建设等任务。

(4) ZUP 按照居民户数对新建大型居住社区进行分级: 居住组团 (200 500户)、邻里单位 (800 1 200 户)、街区 (1 500 2 500户)、区 (3000 6 000户), 各级单元制定了相应的公共服务设施配套标准。但实际上,由于资金不到位,公共设施的配置普遍出现了滞后现象。此外, 配置标准也过于偪化, 未能对人口结构变动和居民实际需求进行充分调查, 以至供需关系出现了错位。

(5) 受英国新镇和北欧新区理论影响, 法国从 1960 年代初期开始探索新城建设, 试图将大型居住社区置于城市环境, 以避免就业岗位匮乏的问题。 1965 年版的巴黎总体规划提出“在市区外 $30 \mathrm{~km}$ 设置 8 个新城, 规划疏散人口 30 万”。这些新城是完整意义的市镇, 有充足的就业岗位、公 共服务设施和多样化的住宅供给 (高档、中产和社会住房)。不久, 其他法国城市如里昂、马赛、里尔、鲁昂等也陆续建立了新城计划, 但计 划的实施到 1970 年代才真正开始。经过 30 年的发展, 无论是巴黎新城还是外省新城, 入驻企业的数量都远低于预期, 就业的匮乏使得大部分 的中高收入居民还是选择离开。截至 2000 年, 全国仅建成 9 个新城, 新城住宅仅占大型居住社区建设量的很小部分。

(6) ZAC 建立于 1967 年, 是针对城市公共项目（社会住宅、医院、学校、市政设施等）开发的一种法定规划。ZAC 的任务是“在政府和私人开发 商之间, 就项目规划、资金来源、分期实施和影响评估四方面形成开发协议”，其成果既可以单独作为法律文件，也可以纳入相关市镇的地方 规划。与 ZUP 相比, ZAC 更加注重开发区的产业发展和地区活力, 编制过程也出现了权力下放的趋势。

(7) 截至 1980 年, 全法划定了 1617 个 ZAC, 其中有 $37 \%$ 的产业区和 $5 \%$ 的旅游区用于改善大型居住社区的就业和地区活力。在实施 ZUP 和 ZAC 期间, 法国每年住宅建设量接近 30 万套，1970 年代初达到 50 万套。20 年建设了 600 万套，其中 $90 \%$ 受到国家资助 ${ }^{[16] 。}$

（8) 1962-1963 年调查公司 CINAM 对四个典型大型居住社区进行了人口调查。从收入水平看, 大型居住社区高收入居民的比例并不低, 而低 收入居民（工人、职员和低端服务业）的比例低于地区平均水平；从就业率看，大型居住社区家庭就业人口的失业率仅 $9 \%$, 远低于当时 $50 \%$ 的全国水平; 从年龄构成看, 住房条件的改善和低廉的价格主要吸引的是“年轻的核心家庭” (即夫妻年龄在 20 45 岁, 有 $1 \sim 2$ 个孩子)。 也就是说, 从收入、职业和年龄构成来看, 大型居住社区的初衰并不是要建造低收入社街区, 而是要创造一个 “多元人群高密度混居的社区” 117$]$ 
首先, 战后经济的快速增长使得法国人均年收人提高了 $50 \%$, 中产阶级迅速扩大, 社会进人了消费时代。1 970 年 代以后, 政府推出鼓励私人购房政策 ${ }^{1}$, 中产阶级纷纷离 开大型居住社区, 回到市区公寓或在郊区购置独立别墅。 其次, 战后重建吸纳了大量的外来移民, 他们的住房需求 在经历了生育高峰之后变得更加迫切。宽松的移民政策 (特别是住房) 帮助他们逐渐进人大型居住社区, 填补了 中产的空缺。最后, 1970 年代中期的经济危机引起了工 厂企业的大规模裁员, 工人家庭失去了进一步改善居住条 件的能力一一大型居住社区逐渐成为低收人人群和外来移 民的聚居地, 并在就业、教育、安全等方面出现了全面的 衰退。

战后 30 年的大型居住社区建设存在多种类型和方式 (集合住宅、新城、ZUP、ZAC)，但其空间特征呈现出一 定的连续性。一方面, 大型居住社区住房在数量和质量方面 获得了双重提升：快速建造及时缓解了战后的住房紧缺, 住 宅在居住面积、采光通风、厨卫浴设施等方面也得到了全面 的改善 ${ }^{2}$ 。另一方面, 大型居住社区在空间规划上的失误也 无法回避。一是选址偏远。受土地供应的限制, 大型居住社 区与市中心的平均距离一般在 30 50 km, 联系主要依靠市 郊铁路, 居民的出行和工作成本过高。二是超大规模。早 期对大型居住社区规模的要求是 “大于 500 户, 但不超过 1000 户”, 但中后期的大型居住社区不断突破这一限制。 户数的膨胀导致了住宅体量、街区尺度和公共服务设施规 模的失控, 也彻底改变了城市交通、地区景观和居民日常 生活方式 ${ }^{3}$ 。第三, 大型居住社区是现代主义规划原则（雅 典宪章）的实践者。区内采用严格的功能分区, 标准化房型 和服务设施的均等化配套。住宅建筑形式简单划一, 所有内 部道路和单元楼都以数字命名, 行列式板楼和高大塔楼在获 得了采光通风的最佳条件的同时, 也丧失了人性尺度和空间 特色。第四, 大型居住社区突元的建筑形象和封闭式管理与 周边地区的城市功能、肌理和景观格格不人, 为日后的居住 隔离埋下了隐患。

\section{5 从街区到城市、从国家到社会一大型居住社 区的更新与治理}

对大型居住社区的反思在 1970 年代有了实质性的 结果一一法国建设部在 1973 年的《吉查尔公报》(1a Circulaire Guichard) 中指出, 大型居住社区的超大规模对 贫困人口的聚居负有直接责任, 必须回到混合居住的初衷 上来一一 “立即停止新建大型居住社区, 对在建大型居住 社区进行调整, 调整的要求是 : 一、大型居住社区规模严 格限定在 2000 户以下; 所在市镇人口少于 5 万的大型居住 社区不得超过 1000 户; 二、大型居住社区中的社会住房的 比例应超过 $20 \%$, 但不得高于 $50 \%$ ”。这份公报标志着持续 了近 30 年的大型居住社区建设进人尾声, 大型居住社区的 更新与治理被提到议事日程上来。

1970 年代以后的法国大型居住社区治理经历了四个 阶段。

（1）调查诊断（1975-1980 年)。1975 年建设部联合 “社会行动与健康部” 成立了跨部门工作组 “住房与社会生 活计划” (HVS), 负责调查大型居住社区的物质和社会环境 变化, 并在两年后公布了第一批 (50 多个大型居住社区) 的 调查报告。这份意见尖锐的报告成功预见了 1980 年的法国 第一起郊区暴乱, 引起了全社会的关注。1980 年代初, 大 型居住社区的参与者一廉租房办公室、混合企业联盟、行 业住房联合会、法国市长协会、城市规划事务所联盟、家庭 补助局等机构纷纷开展调查, 并在各自职能范围内开始调整 住房政策。

（2）街区治理（1981－1990 年)。1981 年法国左派政党 上台, 建立了“街区社会发展国家委员会” (CNDSQ)。委 员会联合中央政府、省、市、各部委及相关企业和社会组织, 共同签订了针对大型居住社区更新的行动计划—《街区社 会发展计划》(DSQ)。该计划提出了“地域化” 的策略 ${ }^{(4)}$, 在五年时间里（1984-1988 年）重新划定了全国敏感街区, 对其中的 148 个大型居住社区、150万居民进行了调查。针 对失业率、犯罪率高以及青少年社区融人的突出问题, 提出

(1) 鼓励政策 (1977 年) 包含两个内容: 一是国家对住房建设货款的重点从租货房转向商品房; 二是提供了私人购房补贴, 国家的住房补贴政策 从过去的资助“砖头”转向资助 “人头”。

(2) 二战结束时, 法国有 $1 / 3$ 住房拥挤, $1 / 2$ 没有上下水, $3 / 4$ 没有独立侧所, $90 \%$ 没有浴室, 还有 35 万处棚户区。而在新建大型居住社区中, 每 户都有独立㕌卫和南向客厅或卧室, 户均房间数也达到 3.3 个 (高于当时 3.1 的国家水平) ${ }^{[12]}$ 。

(3) ZUP、ZAC 时期的大型居住社区规模逐渐到了 4000 户以上, 个别如米拉尔 (Mirail)、萨尔塞勒 (Sarcelles)、埃卢维尔一圣- 克莱尔 (HerouvilleSaint-Clair) 等超过 10000 户, 最大的安努伊一塞夫朗（Anlnuy-Sevran）达到 18500 户。封闭街区长达几公里, 南锡市 (Nancy) 的上列夫街区 (Haut-du-Lievre) 连续板式住宅长达 $400 \mathrm{~m}$, 南特市（Nantes）郊区的一处大型居住社区还出现了4000户居民共用一个电梯的情况。

(4) 所谓 “地域化” 策略, 是指社会发展的政策制定不再针对某类特殊的社会群体, 而是针对他们居住的敏感街区, 例如居住改善区、教育优先发 展区和经济复兴区等等。至 1980 年末, 法国全国划定了大约 500 多个各类敏感街区, 1998 年增加到 750 个, 平均每 12 个法国人中就有一个 住在敏感街区 ${ }^{[18]}$ 。 
了大型居住社区更新的三大策略 : 全面综合、居民参与、多 方协作 ${ }^{(1)}$ 。

（3）城市政策（1990-2000 年)。经济增长的持续放缓 使得 1980 年代街区治理的效果十分有限。政府逐渐意识到, 大型居住社区问题虽然集中表现在街区尺度, 但其根源却在 城市, 乃至整个社会经济运行系统中。1990 年, 在多年的 跨部门行动经验之上, 法国成立了 “城市部”, 负责城市住房、 健康、就业和社会团结等综合性问题, 并将《街区社会发展 计划》更名为《城市社会发展计划》(DSU), 随后又统称为 “城市政策” (la politique de la ville) (2)。1995 年在新成立的 “国土整治和地区行动委员会”（DATAR）的协调下, 国家、 省、市地方政府、社会住房办公室等机构再次签订 “协同行 动合约”, 明确了城市政策的实施对象是 750 个市镇的 1300 个大型居住社区, 实施内容包括住房与空间整治、公共服务 设施调整、经济发展和社会融入、预防犯罪和社区融合四大 板块。与 1980 年代的 “街区治理” 相比, “城市政策” 有两 个重要调整 : 一是更加注重城市视角和部门协同行动; 二 是对于划定的敏感街区, 政府准备了一整套刺激地方经济和 社会发展的政策, 包括提供更多的就业岗位, 优先供给公共 服务, 为区内企业减税, 为房地产开发提供贷款优惠, 资助 失业者再就业, 提升住房多样化和居住环境, 降低商业和不 动产印花税等等。10 年的 “城市政策” 虽然未能扭转局面, 但有效阻止了敏感街区的恶化, 税收和社会住房在市镇之间 的再分配也及时避免了贫富差距的扩大。

（4）社会团结（2000-2010 年)。2000 年以后, 多起郊 区骚乱暴露出大型居住社区的青少年在身份认同和社会融合 方面的困境, 大型居住社区治理开始聚焦新的目标——以 城市更新促进社会团结”。2000 年通过了《社会团结与城市 更新法》(SRU) ${ }^{3}$, 随后成立了 “国家城市更新局” (ANRU)。 更新局在 2003 年推出新政, 对 “敏感街区的空间与社会结 构” 进行调整, 调整的内容包括 : 一、住宅类型多样化。对 全国 750 个敏感街区中 $10 \%$ 的社会住房（主要是 19501960 年代建造的高层塔楼) 进行拆除, 用小体量的普通商品 房和中高档租赁房替代; 二、重塑地方性。通过环境整治和 引人优质公共资源来提升街区宜居度, 通过教育培训和文化 活动来增强社区凝聚力和减少社会歧视, 改变公众对大型居
住社区的负面印象。截至 2013 年, 更新行动共拆除和新建 社会住宅 140 套, 改造 300 万套, 城市新增的公共设施也大 多优先布局在敏感街区。与空间更新的效果相比, 社会更新 的效果却不甚理想——新的调查显示, 住房重建之后, $50 \%$ 的原住民还是回到大型居住社区， $40 \%$ 的原居民选择大型居 住社区所在市镇, 只有少数 “职业和收人相对稳定的年轻居 民” 真正地选择离开大型居住社区 ${ }^{\circledR}$ 。这说明虽然存在种种 问题, 但绝大部分居民对大型居住社区的归属感依然很强。 “以更新促团结”的理想并没有实现，贫困人口在空间上的 聚集反而有加强的趋势。

\section{6 结语}

一个半世纪的法国大型居住社区建设与治理大致可以分 为四个阶段, 各阶段在背景、思潮、政策、社会和空间方面 都呈现出不同的特征 (表 1)。

法国经验显示, 大型居住社区是时代产物, 它既受到经 济条件的制约, 也是社会思潮和城市理论的反映。从政策角 度看, 除了早期的工人之家, 法国社会住房的建设和治理一 直由中央政府主导：国家通过直接投资、立法、组织协同行 动等多种方式积极介人。这体现了法国中央集权的传统和平 等团结的价值理念, 也表明欧洲福利国家对房地产市场始终 保留干预权力的态度。从社会角度看, 虽然大型居住社区的 服务对象以中低收人家庭为主 (特别是工人阶级), 但大型 居住社区建设是全社会参与的结果: 从企业主、工人合作社、 混合公司、民间社团到公众参与, 社会力量在各个时期从未 缺席。从空间角度看, 从几十户的集合住宅到户数过万的大 型社区, 从花园别墅到高层塔楼, 从街区到市镇, 法国大型 居住社区尝试了多种空间类型和治理方式, 在社会住房的投 资、建造和治理方面积累了丰富的经验和教训。

160 年的法国大型居住社区理论与实践无疑具有重要的 借鉴价值, 现有文献对法国社会住宅的投资建造方式、以社 会融合为目标的住房政策, 以及带有公正社会理想的城市治 理政策等方面已有部分的介绍与梳理 ${ }^{[19.23]}$ 。本文从历史视角 出发, 对法国大型居住社区的缘起、发生、发展和衰败过程 从背景、政策、社会、空间四方面进行全景式的分析, 为理 解上述具体议题提供重要背景。在城市规划的国际经验比较

(1) “全面综合”指大型居住社区更新的策略不能仅从结果 (功能失配和物理空间衰败) 出发, 还要从原因(社会经济背景、失业、青少年教育、 贫困化和区隔) 入手; “居民参与” 是指大型居住社区更新要听取居民意见,请居民参与到更新行动中来; “多方协作”是指结合 1982 年法国《地 方分权法》, 将过去集中在中央政府手中的大型居住社区建设和管理权部分下放到地方政府, 由后者来动员企业和社会组织参与更新行动。

(2) 将 “街区” 更名为“城市”一方面体现了治理者思路的转变 (将大型居住社区问题放在城市尺度下审视), 另一方面也避免了对敏感街区污 名化的倾向。

(3) SRU 法确立了社会混合的空间策略, 即 2002 年 1 月 1 日以后的 20 年中, 巴黎大区内 1500 人以上的市镇, 以及其他 50000 人口以上的聚居 区中人口超过 3500 人的市镇, 社会住宅在住宅总量中的比例必须达到 $20 \%$ 。

(4) 来自让一伊夫・奥捷 (Jean-Yves Authier) 教授 2015 年 3 月 18 日在同济大学的讲座。 
杨辰 | 政策、社会、空间—法国大型居住社区的建设与治理（1850-2010 年)

表 1 法国大型居住社区建设与治理的分期与主要特点

\begin{tabular}{|c|c|c|c|c|c|}
\hline 主要阶段 & 时代背景 & 思潮与原则 & 代表性政策 & 服务对象与参与者 & 空间特征 \\
\hline $\begin{array}{l}\text { 工人城 } \\
\text { (1850-1890年代) }\end{array}$ & $\begin{array}{l}\text { 工业化; } 1848 \\
\text { 年革命 }\end{array}$ & $\begin{array}{l}\text { 城市美化与卫生运 } \\
\text { 动; 工团主义; 空想 } \\
\text { 社会主义 }\end{array}$ & 《公共卫生法》; 合作社集资 & $\begin{array}{l}\text { 工人家庭 ; 政府, 工人合作社 ; } \\
\text { 慈善家 (企业主) }\end{array}$ & $\begin{array}{l}\text { 工人公寓 (市区) ; 工人新村 } \\
\text { (郊区) ; 工人之家 (远郊) }\end{array}$ \\
\hline $\begin{array}{l}\text { 花园城 } \\
\text { (1890-1930年代) }\end{array}$ & $\begin{array}{l}\text { 巴黎公社; 战 } \\
\text { 后重建 }\end{array}$ & $\begin{array}{l}\text { 田园城市; 工业城市; } \\
\text { 现代主义 }\end{array}$ & $\begin{array}{l}\text { 《施格弗莱德法案》; 《斯特劳斯法 } \\
\text { 案》; 《博纳韦法案》; 《城市规划 } \\
\text { 法》; 《卢舍尔法案》 }\end{array}$ & $\begin{array}{l}\text { 工人阶级与低收人群体; 政府, } \\
\text { 合作社, 混合公司, 民间社团（社 } \\
\text { 会研究院基金会） }\end{array}$ & $\begin{array}{l}\text { 廉价房 (HBM) ; 单一居住功 } \\
\text { 能; 选址靠近工业区; 多层高 } \\
\text { 密度开发 }\end{array}$ \\
\hline $\begin{array}{l}\text { 大型居住社区 } \\
(1945-1973 \text { 年) }\end{array}$ & $\begin{array}{l}\text { 战后重建 ; 经 } \\
\text { 济复苏 }\end{array}$ & 雅典宪章 ; 发展主义 & $\begin{array}{l}\text { 修订《城市规划法》; 优化城市化 } \\
\text { 地区 (ZUP) ; 协议开发区 (ZAC) }\end{array}$ & $\begin{array}{l}\text { 混合社区, 贫困居区; 政府, 开 } \\
\text { 发商, 公共机构, 土地所有者 }\end{array}$ & $\begin{array}{l}\text { 选址偏远 ; 规模超大 ; 功能分 } \\
\text { 区; 封闭管理 }\end{array}$ \\
\hline $\begin{array}{l}\text { 更新与治理 } \\
\text { (1973-2010 年) }\end{array}$ & $\begin{array}{l}\text { 消费时代 ; 移 } \\
\text { 民需求 ; 经济 } \\
\text { 危机 }\end{array}$ & $\begin{array}{l}\text { 地方分权 ; 社会融合 } \\
\text { 与团结 }\end{array}$ & $\begin{array}{l}\text { 《吉查尔公报》; 街区治理 (DSQ); } \\
\text { 城市政策 (DSU) ; 《更新与社会 } \\
\text { 团结法》(SRU) }\end{array}$ & $\begin{array}{l}\text { 减少低收人居民, 增加中产家庭 } \\
\text { (但尚未成功); 政府各部, 社 } \\
\text { 区组织, 公众参与 }\end{array}$ & $\begin{array}{l}\text { 拆（高层）补（小体量）; 街 } \\
\text { 区环境整治; 公共资源的优先 } \\
\text { 供给 }\end{array}$ \\
\hline
\end{tabular}

资料来源：作者整理

与借鉴中, 政策、经济、社会的背景分析往往是关键, 忽视 了背景差异, 将会造成比较和借鉴的无效。

法国大型居住社区对于中国保障房社区建设具有三方面 的借鉴价值。其一, 受人口、土地、财力和权力结构的约束, “法 国是西方资本主义国家唯一一个以大规模集合住宅的形式 (多层行列式和高层塔楼为主) 来缓解住房短缺的国家” ${ }^{[24]}$, 这与东亚城市保障房社区的高密度特征较为接近。大规模集 中建造虽然可以短时间内缓解住房紧张, 但从长远来看, 大 型居住社区造成贫困人口聚集和社区衰败的风险极高, 且一 旦建成, 极难调整。这无疑是对中国当前保障房建设的重要 警示。其二，法国大型居住社区的建设时间跨度大，类型多 样, 群体多元。从 1850 年的第一座工人城到 1970 年代的新 城建设, 从工人阶级到低收人居民、中产阶级, 再到外来移 民, 不同时期的大型居住社区接纳了不同的社会群体, 由此 产生的身份认同、混合居住和社区融合等问题成为法国当代 社会建构的重要议题——这也是当下中国保障房社区面临的 主要问题。其三, 法国有集权和市民社会双重传统, 国家和 市场在社会运行中各自扮演着重要的角色, 大型居住社区建 设也不例外一一中央和地方政府、混合企业以及各类社会组 织都是主要参与者。特别是 1980 年代以来, 政府动员社会 力量对大型居住社区展开更新行动的策略和方法值得中国保 障房社区的建设和管理者进一步研究与借鉴。 UPI

\section{参考文献}

[1] 熊健. 上海大型居住社区规划的实践和思考 [J]. 上海城市规划, 2011(3): 36-40.

[2] 俞斯倩. 社区规划在大型居住社区建设中的实践一以上海宝山区顾 村一号基地为例 [J]. 上海市城市规划, 2011(3): 50-57.

[3] 张萍, 杨东援. 上海外围大型社区居民属性和出行行为 [J]. 城市规划, 2012(9): 63-67.

[4] 安钊. 城市动迁居民的居住模式与家庭结构的演变 [D]. 华东师范大学 硕士论文, 2007.
[5]彭善民、新建大型居住社区管理的困境与创新 [J]. 学术评论, 2012(1): 99-104.

[6] 骆雁南. 制度安排与行动力: 城市动迁居民自主返迁与社区空间重构 [D]. 华东师范大学, 2012.

[7] Rotival M. Les Grands Ensembles[J]. L'Architecture d'Aujourd'hui, 1935, 1(6): 57.

[8] Dufaux F, Fourcaut A. Le Monde des Grands Ensembles[M]. Paris: Créaphis, 2004: 45 .

[9] Chamboredon J-C, Lemaire M. Proximité Spatiale et Distance Sociale: Les Grands Ensembles et Leur Peuplement[J]. Revue Française de Sociologie, 1970, 11(1): 3-33.

[10] Mengin C. La Solution des Grands Ensembles[J]. Vingtième Siècle, Revue d'Histoire, 1999, 64(10-12): 105-111.

[11] 吴清军. 西方工人阶级形成理论述评一一立足中国转型时期的思考 [J]. 社会学研究, 2006(2): 182-203.

[12] Merlin P. Les Grands Ensembles[M]. Paris: La Documentation Française, 2010: 36,44,72.

[13] Guinchat P, Chaulet M P, Gaillardot L. Il Était une Fois l'Habitat: Chronique du Logement Social en France[M]. Paris: Editions du Moniteur, 1981: 126.

[14] Stébé J M. La Crise des Banlieues: Sociologie des Quartiers Sensibles[M] // Coll. Que Sais-Je?. Paris: Puf, 2007.

[15] Tissot S. L'Etat et les Quartiers: Genèse d'une Catégorie de l'Action Publique[M]. Paris: Seuil, 2007.

[16] Wikipedia. Grand Ensemble en France[EB/OL]. [2016-08-07]. https:// fr.wikipedia.org/wiki/Grand_ensemble_en_France.

[17] Merlin P. Les Banlieues des Villes Françaises[M]. Paris: Les Études de la Documentation Française, 1998.

[18] Fijalkow Y. Sociologie de la Ville[M]. Paris: La Découverte, 2002: 61.

[19] 白晨㬢。法国社会住宅的融资与建设 [J]. 国际城市规划，2004(5): 22-27.

[20] 赵明, 弗兰克. 舍雷尔. 法国社会住宅政策的演变及其启示 [J]. 国际城 市规划, 2008, 23(2): 62-66.

[21] 刘健.城市快速发展时期的社会住房建设：法国的教训与启发 [J]. 国 际城市规划, 2012(4): 3-12.

[22] 陆超, 庞平. 居住隔离现象的内在机制探索与对策研究——法国大型社 会住宅建设对中国大型保障房建设的启示 [J]. 城市规划, 2013(6): 52-56.

[23] 孙莹. 法国社会住房的政策演变和建设发展 [J]. 国际城市规划, 2016(6): 81-88

[24] Fourcaut A. Qu'elle Était Belle la Banlieue[M]. Paris: L'Histoire, 2006.

(本文编辑：张祎娴) 